\title{
ACADEMIC AND METHODOLOGICAL ASPECT OF TRAINING FUTURE SOCIAL WORKERS FOR PROFESSIONAL ACTIVITY WITH YOUNG FAMILIES
}

\author{
M. Dovga
}

In modern social conditions, the family is in a crisis phase of its existence due to the low economic development of society and requires necessary support and social and legal protection from the society and the state to overcome the recurrent problems. This also requires the help of qualified social workers, who must be professionally trained to provide assistance to various types of families in difficult life circumstances. Therefore, we have determined the expediency of vocational training of future social workers for working with young families at the current stage of Ukrainian society development concerning gaining solid knowledge and ability to possess practically and apply in the protection of client groups, that is young families, in our case. We have considered the concept of "social worker" and its role as a specialist in the social and pedagogical sphere, as well as some aspects of a social worker's work with young families, which is carried out by preparing young people for family life, stabilization of family relationships, solving problems, related to family education and social rehabilitation of a young family. Therefore, taking into account the transformational changes in family relations and changes in family values in young families at the present stage of the development of Ukrainian society, it is necessary to emphasize the proper professional training of future social workers to work with this category of families. Moreover, based on the considered educational programs and working curricula of higher educational institutions, specified in the paper, an academic and methodological complex of the special course "Fundamentals of the social and legal protection of young families" has been developed to improve the training of future social workers for working with young families. It is based on the training of social workers for solving complex life family problems and specialized problems in the process of acquiring the necessary theoretical and practical knowledge, abilities and skills in the provision of social and legal protection while studying at a higher education establishment. In particular, the concepts and theoretical foundations of social and legal protection, factors and its determinants, the process and procedure of social establishments to provide social and legal protection to young families, familiarization with social phenomena and documents and regulations on the provision of social and legal protection

Keywords: vocational training, social worker, work with young families, academic disciplines, academic and methodological complex

\section{Introduction}

Vocational training of future social workers in higher education institutions for working with young families is quite relevant since a specialist with this category of clients must have a large wealth of knowledge in various fields, as well as skills and abilities to help newly formed families in difficult current circumstances. But this should happen by means of modern educational technologies, taking into account previous domestic and world experience in the social sphere.

Social support for young families as a form of social work is an essential component of the state's activities in relation to society. Such support can improve the quality of life of the Ukrainian population and increase demographic indicators. Social and pedagogical work with a young family is a system of interaction of social bodies of the state, society, and family, aimed at improving its life conditions, expanding opportunities for exercising the rights and freedoms, defined by international and state documents, ensuring full physical, moral and spiritual development of all its members, involving in the labor, social and creative process. Social and pedagogical work with a family in social work is organizational, consultative, and human rights-based, since it is aimed at creating conditions for exercising the rights, interests of children and youth, other family members [1].

In particular, according to I. Litiaha, R. Mykhalkina, one of the important principles of social work with the young family is the principle of family selfsufficiency, observance of which helps to organize social assistance to stimulate the internal reserves of the family, solve their own problems. Moreover, social work with the young family is aimed not only at the family as a whole, but also at its individual members (child, mother, father, and other family members). The effectiveness of fulfilling the main purpose and objectives of social and pedagogical work with the young family is ensured by taking into account the typology and category of families that need different types of social and pedagogical influence, using appropriate forms and methods of work [1]. 


\section{Literary review}

Vocational training of social workers in Ukraine is a structural element of higher education, which began its formation and development after our country gained independence. A need for highly qualified social workers is growing every year, which dictates a need for improvement of the system of vocational training of social workers, the legal framework, governing these processes according to international requirements. A. Popova believes that the content of vocational training of social workers is a direct reflection of events in social policy, regulatory environment, activities of international organizations, the foreign experience of social work, requirements and needs of consumers of educational services of a certain territorial allegiance [2].

Etc. paid attention to the training of social specialists in particular, [3] N. Ostanina considered the professional training of social workers on the basis of a competent approach in the conditions of modernization of higher education. She analyzed the content of the training sessions, through which the formation of professional competence takes place. Also, O. Karpenko [4] in his dissertation for the doctor of pedagogical sciences proposed a new approach of training a professional social worker by building a structural and functional model of such training, development and implementation into the practice of scientific, methodological and organizational and technological support.

Vocational training of social specialists in Ukraine provides for a multilevel nature of education, which is carried out by educational institutions of different levels of accreditation. In Ukraine, the most common and recognized education that can provide a graduate with a job in the specialty is studying in higher education institutions of III-IV levels of accreditation [2].

In particular, H. Mykhailyshyn highlights the formation of a person, who can creatively, consciously, independently determine his/her future activities, capable of self-regulation, which will ensure achievement of this goal, among the main tasks of vocational training of young people at the current stage of education development in Ukraine. Since society needs a specialist, who will work for a specific result, the priority here should be the correct organization of not only training, but also the educational process in higher education [5].

According to the provisions of [6] the Law of Ukraine "On Higher Education", the training of social workers shall be carried out at two educational and qualification levels - the first one, successful completion of which provides for obtaining a bachelor's degree (4 years) and the second one, fulfillment of educational requirements of which leads to conferring a master's degree (1.5-2 years).

\section{Purpose and objectives of research}

The purpose of the research is to consider the educational process organization in higher education institutions concerning training of students as future social workers for professional activities with young families as a result of the formation of necessary knowledge and skills for working with this category of persons.

According to the purpose of research, the following tasks have been identified:
1. To analyze the educational process organization in higher education institutions concerning training of future social workers for working with young families;

2 . To improve the conditions of vocational training of future social workers for working with young families that need social and legal protection.

\section{Materials and methods}

The following methods have been used to achieve this goal: monographic (comprehensive and in-depth study of the concept of social worker, the problem of educational process organization in higher education institutions concerning vocational training of future social workers for working with young families at the current stage of the Ukrainian society development); comparative (comparison of different opinions of scientists on the concept of the social worker to establish the specific nature of the problems of vocational training of future family specialists) and abstract-logical (an academic and methodological complex of the special course "Fundamentals of the social and legal protection of young families" has been developed and conclusions on improving the vocational training of future social workers for working with young families to provide social, legal and pedagogical assistance to this category of families have been provided).

\section{Research results and their discussion.}

According to the Law of Ukraine "On Social Services", a social worker is a professionally trained specialist, who has the necessary qualifications in social work and provides social services [7].

Any social worker puts a focus in his/her functional purpose on his/her ability to create and develop relations between people, between a human and his/her environment, ability to intensify the efforts of a staff to solve their problems, ability to serve as a mediator, and mend relations between conflicting individuals, groups, provide interinstitutional relations. Since a social worker deals with a human and his/her environment (and above all, with his/her family), it is emphasized, that knowledge of human development and behavior in a particular environment is necessary for each social worker, whoever his/her client is - a child or adult, single retired or disabled person, family or another social group. This means that the psychological and pedagogical competence in the personal and environmental context of the specialist is the basis of his/her functional literacy, qualification [8].

A family social worker specializes in providing comprehensive family assistance. Clients of a family social educator (worker) are single-parent families living in one or more nearby houses. Now, this is the most common and most popular option for a multi-skilled specialist that is a basic component in the staffing infrastructure of the social service system. The family worker is a specialist of the highest qualification, with extensive life experience, competent and respected in the neighborhood, where he/she works, has skills of direct professional activity, associated with the delicate entry into the family and organization of comprehensive family assistance in ethically acceptable forms, based on the involvement of the family in this process [8]. 
N. Ostanina states that a social worker is a specialist, who can work at different levels of the state's social policy implementation - at the level of management, logistics and legal support, education, health care and, directly, social work practice. Moreover, a social worker must be a participant in joint activities, organizer of this activity that leads a human for a long time, provides support, cares about formation of social values in society that is acts as an integral subject of professional activity [2].

Modern family focuses the entire set of social problems, inherent in modern society, lifestyle. Among them, you can highlight your own family problems. This is the division between spouse family roles and the struggle for leadership, the need to communicate with individual family members and the impossibility of its implementation in the family due to various reasons, lack of cognitive needs (for example, knowledge and skills to educate children, etc.) in individual family members or in general in the family, inadequacy of assessments of children's behavior, brutal interference in their inner world, emotional rejection up to de-edification and cruel appeal, which contributes, in the presence of children and adolescents of different accentuation of character, to the development of their deviant behavior; the presence of a negative ethical and psychological atmosphere in the family; unsatisfactory material needs of the family and many others [9].

The family as a social establishment is in a state of acute crisis, which, of course, adversely affects the fulfillment of its main functions, that is, the life of the family: logistical support, housing and household conditions. This, in turn, creates a certain moral and psychological climate that affects the spirituality of the family, the education of children, the organization of free time of family members. In particularly difficult conditions during the crisis is a young family, which, according to the Law of Ukraine on promoting social formation and development of youth in Ukraine, is defined as a couple, in which the age of husband and wife does not exceed 35 years, or a part-time family, in which the mother (father) is under the age of 35 years [10].

Therefore, working with young families in the social sphere differs from other activities of a social worker. The young family is a newly formed family that needs to understand all realities of family life, as well as form and affirm certain family stereotypes and values in their formed family. Young people should be ready to build family relations, because then they respond more reasonably to certain family situations. They should also try to stabilize family relations and avoid conflict situations.

The young family differs from other types of families in the fact that the main direction of its development is the relations between husband and wife, which are key in the family environment and play an important role in raising offspring. The main directions of social and pedagogical work with the young family are:

- preparation of young people for family life; lations;

- work with young families to stabilize family re-

- assistance to parents in solving problems of family education;

- social rehabilitation work with a family [1].
Taking into account the current realities of social relations, it is important to improve the quality of social and pedagogical work with young families, since such family is under threat, just like the entire institution of family. Taking into account that any family begins its stage of existence as a young one, it is necessary to learn how to preserve it and lay the foundation for further existence to avoid divorced families, single-parent families, problems of upbringing in two-parent and single-parent families, etc. And for this, it is necessary to improve the training of a specialist in this field, which would be the study of necessary disciplines by students as a whole to master all problems of working with young families.

We have analyzed educational programs and working programs of disciplines 23 "Social work" in specialty "Social work" concerning training of bachelors of social work at Vasyl Stefanyk Precarpathian National University, Kyiv-Mohyla Academy, Kherson State University and Podilsky Special Educational and Rehabilitation Socio-Economic College, which basic and elective disciplines, related to working with young families, are taught: Social Pedagogy, Social Psychology, Fundamentals of Counseling, Theory of Social Work, Legal Fundamentals of Social Work, etc. In order to improve the vocational training of future social workers for working with young families, we have developed an academic and methodological complex of the special course "Fundamentals of the social and legal protection of young families".

The special academic course "Fundamentals of the social and legal protection of young families" is the theoretical basis of psychological training of bachelors, who obtain the educational and qualification level of a bachelor; it directs the bachelors to study the mechanisms of the social and legal protection of young families, understanding the patterns of formation and development of young families, features of social and legal activities of social workers with young families, as well as provides for practical mastery of skills and abilities of social and legal, and pedagogical work with young families.

Purpose: training of specialists, who can solve complex specialized problems and applied social problems or to master the concepts and theoretical basis of the social and legal protection of young families, children and parents when learning; formation of ideas about social factors and determinants of organization of the social and legal protection of young families; management of this process according to the structure and functions of certain social institutions, which provides for use of certain theories and methods of social work; acquaintance with social phenomena that mediate and cause social and legal protection, as well as social and legal documents and acts.

The main tasks of studying the discipline "Fundamentals of the social and legal protection of young families" are:

- to acquaint students with the theoretical background of this special course;

- to learn the basic concepts of the rights and responsibilities of children and parents; international and national regulations concerning social protection of young families and their maintenance; 
- to explain an impact of regulations on the family life of young people;

- to learn to protect their rights in order to prevent violations of the rights of young families;

- to create conditions for students to master the essence of the content and organization of the main activities of a social worker with young families in social institutions.

As a result of studying the discipline, students should know:

- theoretical aspect and technologies of work with young families;

- historical and methodological origins of the social and legal protection development in Ukraine and industrialized countries; directions of its improvement;

- psychological essence and philosophical foundations of the social and legal protection of young families;

- tasks, content and forms of work when carrying out the social and legal protection of young families;

- regulatory support of the social and legal protection of young families.

As a result of studying the discipline, students should be able to:

- analyze and determine the needs of young families and scientific sources concerning them, learn to know the social and legal categories and concepts;

- collect and evaluate information about the problems of young families;

- apply skills to analyze independently and implement creatively measures to solve problems that arise in young families, as well as formulate recommendations for solving real-life situations;

- identify, plan and apply the acquired knowledge in future activities with young families;

- use modern methods and forms of work when working with young families, as well as form their individual style of future professional activity, professional and pedagogical communication.

The program training outcomes are: higher education students must be able to search and analyze information from different sources to solve professional problems and establish cause-and-effect relations between social events and phenomena; identify and solve problems in social work with young families, integrate practical knowledge and practical experience; formulate their own opinions, based on analysis of the social problem in young families; give reasons for the ways to overcome problems and difficult life circumstances in young families, choose the effective methods to solve them, anticipate the consequences; develop plans, programs of activities, make promptly effective decisions in difficult situations; analyze a current social policy of the country concerning carrying out of social and legal protection of young families and operation of state programs; use relevant research and apply professional skills when providing young families with social assistance; analyze social processes in young families; use prevention methods to prevent behavior disorder, violation of relations, and avoid problems, to resolve family conflicts, as well as to prevent social risks and difficult life circumstances; determine the content of cooperation with partner organizations in social work to perform the tasks of professional activity with young families; use social diagnostic methods, when assessing the problems, needs, specific features and resources of clients among young families; determine circumstances to find out which social assistance is needed; make practical decisions to increase the social and legal protection of young families; establish and maintain relations with young families, based on a mutual trust and according to ethical principles and standards of social work, provide them with social and legal support and encourage them; establish cooperation with representatives of various professional groups and communities, use strategies of individual and collective representation of interests of young families; determine strengths and involve the personal resources of young families, the resources of social groups and communities to solve their problems when overcoming difficult life circumstances; demonstrate tolerant behavior; demonstrate the ability to solve problems creatively among young families and make innovative decisions, think and apply creativity to form fundamentally new ideas; plan the process and result of social work within the tasks in working with young families, use quantitative and qualitative indicators, adjust the work plan according to the assessment results.

The discipline curriculum consists of two content modules: Module1. Theoretical and methodological aspects of the social and legal protection of young families and Module 2. Technologies and forms of social and pedagogical work with young families. The total number of hours is 90 hours, 18 hours of which are assigned to lectures, and 16 hours are assigned to seminars, 56 hours independent work. The form of control is credit.

Methodological support includes: lecture (problem lecture, lecture-dialogue, lecture-press conference, lecture-conversation), seminars, conversations, narrative; independent work of students, educational discussions that are verbal, visual, practical, problematic and interactive.

Methods of control are the final test work (2 options, 40 test questions each), pedagogical dictation (2 options, 10 questions each), oral examination, notes from the submitted sources, independent work (notes of basic terms, compilation of tables and diagrams), defense of reports-presentations, individual tasks.

\section{Conclusions}

Based on the considered organization of the educational process in higher education establishments on the preparation of students as future social workers for professional activities with young families, the following conclusions can be made:

1. The analyzed educational process in higher education establishments on professional training of future social workers to work with young families shows the inadequate level of preparation of students as future social workers in working with young families due to lack of the academic discipline that would acquaint future social workers with different areas of work with young families. And this category of family requires special attention from the employees of social services, because it is quite difficult for young families to build the right family relationships and preserve family values for further happy family life. 
2. The professional training of social workers to work with young families has been improved by developing an educational and methodological complex on special course "Fundamentals of social and legal protection of young families", which will give an opportunity to form knowledge, abilities and skills in social, legal and pedagogical work with this category of persons. Therefore, to overcome the problems of family life, not only support from the state and society (its social institutions) is needed, but also assistance from a social worker, who would deeply study all the problems of each young family and try to solve them. And for this it is necessary that he/she possesses a thorough level of knowledge from different fields, acquired in the process of professional training in a higher education establishment, because the family as the primary link of society development, its center, needs special attention and care.

\section{References}

1. Litiaha I., Mykhalkina R. Working with young families that need social assistance. Available at: http://eprints.zu.edu.ua/25291/1/ Руслана\%20Михалкіна.pdf

2. Popova, A. S. (2017). Professional training of social workers to the work with migrants in Ukraine. Scientific Bulletin of Mukachevo State University Series "Pedagogy and Psychology", 2 (6), 104-108.

3. Ostanina, N. S. (2016). Professional Training of Social Workers in Conditions of Higher Education Modernization According to Competence-Based Approach Research Notes. Series "Psychology and Pedagogy Research", 1, 204-208.

4. Karpenko, O. G. (2008). Professional training of future social workers in the conditions of university education. Kyiv, 46.

5. Mykhailyshyn, H. Y. (2005). Influence of the educational work system on spiritual development of future specialists in physical education and sports. Pedagogy, psychology and medical and biological problems of physical education and sports, $10,42-44$.

6. On Higher Education (2014). Law of Ukraine No. 1556-18. 01.07.2014. Available at: https://zakon.rada.gov.ua/laws/show/ 1556-18\#Text

7. On Social Services (2003). Law of Ukraine No. 966-IV. 19.06.2003. Available at: https://zakon.rada.gov.ua/laws/show/ 2671-19\#n482

8. Professionalism of a social worker. Available at: https://stud.com.ua/48123/sotsiologiya/profesionalizm_ sotsialnogo_pratsivnika

9. Vytek, K. R. (1988). Problems of Supruzhesk's well-being. Moscow: Progress, 483.

10. On Social Work with Children and Youth (2001). Law of Ukraine No. 2558-III. 21.06.2001. Available at: http://zakon4.rada.gov.ua/laws/show/2558-14

Received date 04.08.2020

Accepted date 10.09.2020

Published date 30.09.2020

Myroslava Dovha, Postgraduate Student, Department of Theory and Methods of Preschool and Special Education, State Higher Educational Institution "Vasyl Stefanyk Precarpathian National University", Shevchenka str., 57, Ivano-Frankivsk, Ukraine, 76018

E-mail: mirosya29@meta.ua 